\title{
Leucovorin Sodium
}

National Cancer Institute

\section{Source}

National Cancer Institute. Leucovorin Sodium. NCI Thesaurus. Code C97555.

The sodium salt of leucovorin, an active metabolite of folic acid, used as an antidote to folic acid antagonists. Leucovorin does not require metabolism by dihydrofolate reductase, the molecular target of folate antagonists and counteracts the toxic effects of these drugs. This agent also potentiates the effects of fluorouracil and its derivatives by stabilizing the binding of the drug's metabolite to its target enzyme, thus prolonging drug activity. In comparison with the calcium salt, sodium salt does not form precipitate when mixed other folate antagonists. 